\title{
PERILAKU SOSIAL KESEHATAN IBU HAMIL DAN MELAHIRKAN (Studi di Kawasan Perbatasan Kecamatan Seluas Kabupaten Bengkayang Propinsi Kalimanatan Barat)
}

\author{
Hasan Almutahar \\ Fakultas Ilmu Sosial dan Ilmu Politik Universitas Tanjungpura \\ Jl Prof. Dr. H. Hadari Nawawi pontianak \\ Email: hasanalmutahar@yahoo.com
}

\begin{abstract}
ABSTRAK. Penelitian ini memfokuskan pada perilaku kesehatan ibu hamil dan melahirkan dengan studi kasus di Kawasan Perbatasan. Disini dijelaskan proses kehamilan dan melahirkan, dimana perilaku sosial disinyalir menggunakan tenaga dukun bersalin (dukun kampung) dari masyarakat lokal.Objek penelitian adalah perilaku sosial kesehatan ibu hamil dan melahirkan di Kawasan Perbatasan Kecamatan Seluas, dengan metode diskriptif. Data yang digunakan terdiri dari data primer dan sekunder dari arsip, dokumen, dan instansi terkait.Penelitian ini menjelaskan fenomena perilaku sosial kesehatan ibu hamil dan melahirkan. Sesuai dengan sifat dari objek penelitian, maka pendekatan penelitian ini adalah kualitatif.Hasil penelitian bahwa perilaku sosial ibu hamil menunjukan kurangnya upaya dari ibu hamil untuk berkonsultasi dengan bidan desa bahkan pihak puskesmas. Hal ini disebabkan oleh minimnya prasana di wilayah setempat, seperti kondisi jalan yang sulit dijangkau untuk mencapai puskesmas dan tempat bidan desa di tingkat kecamatan.Mayoritas masyarakat di kawasan pedesaan terutama di kawasan perbatasan masih mempercayai terhadap mitos yang berkembang di masyarakat. Gejala sosial yang telah membudaya yakni dengan mempercayai bidan kampung atau dukun beranak dapat melakukan persalinan dengan bantuan roh-roh halus. Dalam kepercayaan ini dimulai dengan memberikan sesajian yang dipercaya dapat memberikan keselamatan ibu saat melahirkan, dan terutama bagi anak yang dilahirkan.Masyarakat dikawasan ini memiliki persamaan pola pikir pelayanan kesehatan antara ibu hamil yang menggunakan jasa bidan desa dan tenaga medis yang berasal dari puskesmas. Disisi lain terungkap perilaku sosial ibu hamil dan melahirkan masih bergantung terhadap bidan kampung (dukun beranak) yang menggunakan pola-pola tradisional masyarakat lokal (bersahaja).
\end{abstract}

Kata Kunci :perilaku sosial, kesehatan ibu hamil dan melahirkan, perbatasan

\section{SOCIAL HEALTH BEHAVIOR FROM PREGNANT WOMEN AND CHILDBIRTH (Studies In Border Area Of Seluas, Bengkayang District)}

ABSTRACT. This study focuses on health behavior from pregnant women and childbirth in border area. We described the process of pregnancy and childbirth, which prefer to go to Dukun Kampung's house. Here, as object of research is social health behavior of pregnant women and giving birth in border regions named Seluas, with descriptive methods. The data used consists of primary and secondary data from the archives, documents, and related agencies. This study describes the phenomenon of social and health behavior of pregnant women who also giving birth. In accordance with the object of research, the approach of this research is qualitative. And the result said that the social behavior of pregnant women, showed a lack of effort from pregnant women to consult to their midwife even go to clinic. It is influenced by the lack of infrastructure in the local area, such as road conditions which is difficult to reach to go to health centers or midwives placed in district. Most of the society who lived in rural areas, especially in the border region still believes the myth that developed in the community. Social phenomena that have been cultured to believe that the village midwife or dukun beranak is able to help by the power of fine spirits. In this belief, they provide Sesajen for safety of the mother during childbirth, and especially for the baby. People in this region have a same mindset of health services among pregnant women who use the services of midwives and medical staff from health centers. On the other hand, social behavior revealed maternal still relies on dukun beranak who uses traditional patterns of local communities (earthy).

Keywords: social behaviour, health of pregnant women giving birth, the border.

\section{PENDAHULUAN}

Visi Indonesia Sehat 2015, merupakan gagasan tentang Safe Motherhood dan Making Safer menjelaskan sebuah gambaran langsung tentang penekanan betapa pentingnya kesehatan ibu hamil dan bersalin. Secara makro dan komprehensif, gagasan ini sangat penting dan strategis untuk menjamin lahir dan tumbuhnya generasi Indonesia yang sehat, dan produktif.

Banyaknya ibu sehat menjadi indikator kesehatan masyarakat untuk meningkatkan kualitas perilaku sosial ibu hamil dan melahirkan. Paradigma perilaku masyarakat yang sehat, artinya pembangunan semua sektor harus memperhatikan juga bidang kesehatan.
Terutama harus memberikan kontribusi positif bagi pengembangan perilaku dan lingkungan sehat.Secara makro, paradigma sehat berarti bahwa pembangunan kesehatan lebih memfokuskan prilaku sosial yang promotif tanpa mengesampingkan upaya kuratif dan regabilitatif.

Untuk mewujudkan paradigma perilaku sosial ditetapkan visi Indonesia sehat 2015.Penduduk harus dapat hidup dalam lingkungan sehat, memiliki perilaku sosial dan budaya yang baik, serta dapat menjangkau pelayanan kesehatan masyarakat. Hal ini sebagai upaya untuk mengantisipasi setiap komponen masyarakat diwilayah kawasan perbatasan,terkhusus bagi perilaku sosial ibu hamil dan melahirkan di 
Kawasan Perbatasan Seluas Kabupaten Bengkayang Propinsi Kalimantan Barat.

Data sekunder Puskesmas Kecamatan Seluas Kawasan Perbatasan (2013), yakni untuk desa Seluas, terdapat 439 pasang penduduk usia subur dan terdapat 88 wanita hamil. Padahal sarana penunjang hanya, satu orang bidan desa dan satu orang dokter puskesmas, serta hanya dua orang tenaga pegawai kesehatan. Menurut observasi peneliti yang dilakukan di Kecamatan Seluas Kabupaten Bengkayang Kawasan Perbatasan, menunjukkan belum di gunakannya fasilitas kesehatan secara efesiensi. Hal ini diduga disebabkan oleh wilayah ini masih kekurangan tenaga medis baik bidan maupun dokter spesialis kandungan.

Mengutip Garna (1993:88) sumber daya manusia tenaga medis yang memadai baik kuantitas maupun kualitas, baik itu metode penguasaan, pemberian asuhan dan landasan pendekatan kepada masyarakat yang, tersedianya berbagai sumber fasilitas yang diberikan harus didukung pula komitmen dari pimpinan puskesmas dan budaya lokal yang ada di masyarakat.

Penelitian ini difokuskan pada paradigma perilaku sosial, menurut Skinner (1985:68) paradigma perilaku sosial menekankan pendekatan objektif-empiris terhadap kenyataan sosial, yang berupa perilakuperilaku individu yang nyata. Pokok persoalan ini adalah tingkah laku individu yang berlangsung dalam hubungannya dengan faktor lingkungan yang menghasilkan akibat-akibat atau perubahan pada tingkah laku.Tetapi hubungan fungsional antara tingkah laku dengan perubahan yang terjadi.

Menurut Homans (1961:97) perilaku adalah tindakan atau perbuatan suatu organisme yang dapat diamati dan bahkan dapat dipelajari. Proses pembentukan dan perubahan perilaku dipengaruhi oleh beberapa faktor yang berasal dari dalam dan diluar individu antara lain persepsi, motivasi, proses belajar, lingkungan dan lain sebagainya.Perilaku sosial ibu hamil dan melahirkan dikawasan perbatasan disinyalir mereka tetap mempertahankan kebiasaan nenek moyang hal ini terlihat mereka masih mempergunakan bidan kampung.

\section{METODE}

Dalam penelitian ini yang dijadikan objek penelitian adalah perilaku sosial kesehatan ibu hamil dan melahirkan di Kawasan Perbatasan Kecamatan Seluas, dengan metode diskriptif. Menurut Saefullah (2008:62) metode diskriptif adalah metode yang mencoba untuk memberikan gambaran tentang suatu gejala atau hubungan dua gejala atau lebih.

Data yang digunakan terdiri dari data primer dan sekunder dari arsip, dokumen, dan instansi terkait. Penelitian ini menjelaskan fenomena perilaku sosial kesehatan ibu hamil dan melahirkan. Sesuai dengan sifat dari objek penelitian, maka pendekatan penelitian ini adalah kualitatif.Nasution (1996:52) mengatakan bahwa penelitian dengan pendekatan kualitatif pada hakikatnya mengamati orang-orang dilingkungannya, berinteraksi dengan mereka, berusaha memahami dunia emperiknya, memahami bahasa dan menafsirkan tentang dunia sekitarnya. Dengan demikian pendekatan kualitatif menekankan kepada prosedur penelitian yang menghasilkan data atau informasi kualitatif, yang memungkinkan peneliti memahami perilaku ibu hamil dan menyusui di kawasan perbatasan Seluas.

\section{HASIL DAN PEMBAHASAN}

\section{Pemeriksaan dan Konsultasi Selama Kehamilan}

Pemeriksaan kehamilan merupakan suatu usaha untuk mengetahui kondisi kesehatan ibu hamil, dan kondisi janin yang ada dalam kandungannya. Hal tersebut dilakukan agar kehamilan yang berisiko tinggi dapat diantisipasi sedini mungkin, dan mengetahui pekembangan janin, seperti posisi, letaknya bahkan kondisi kesehatan ibu.

Konsultasi selama kehamilan merupakan suatu cara untuk mengarahkan (membimbing) ibu hamil, agar selama kehamilan maupun setelah melahirkan kondisi ibu dan janin selalu dalam keadaan sehat. Untuk itu perlu kesinambungan dalam berkonsultasi dan pemeriksaan kepada tenaga medis yang ada di puskesmas.

Hasil temuan juga terungkap bila tempat pelayanan kesehatan puskesmas relatif jauh, dan terlihat prasarana jalan dari rumah penduduk tidak dapat dilewati roda empat. Ungkapan tersebut dapat ditelusuri secara mendalam, perilaku sosial ibu hamil mereka memeriksakan dan berkonsultasi ke puskesmas dengan tenaga medis sangat kurang. Karena alasan tertentu pula ada perilaku sosial ibu hamil yang tidak memeriksakan dan berkonsultasi ke bidan dan puskesmas.Sehingga mereka lebih banyak berdiskusi dengan dukun kampung (bidan kampung).

Berikut ini temuan lain salah seorang informan mengungkapkan tidak pernah melakukan pemeriksaan dan berkonsultasi selama kehamilan.

"Dari pertama saya mengetahui bahwa saya hamil, saya tidak pernah periksa.Kebetulan waktu hamil saya tidak mengalami kelainan, tapi setelah anak lahir dan berusia 4 tahun baru ketahuan bahwa anak saya menderita penyakit kuning".

Jawaban dari informasi tersebut dapat ditelusuri bila tingkat kesadaran subyek dalam menjaga dan merawat kehamilan masih rendah.Hal ini disebabkan masih kurangnya pengetahuan mereka tentang arti pentingnya menjaga dan merawat kesehatan selama fase kehamilan.Keadaan ini berhubungan dengan masih terbatasnya tingkat pendidikan dan pengetahuan pengetahuan tentang fase kehamilan yang mereka miliki. Terungkap bahwa penduduk (ibu hamil) diwaktu pemeriksaan melalui dukun kampung,.

Informasi penulis peroleh dari salah seorang bidan yang bertugas di salah satu puskesmas yang ada diwilayah Kecamatan Seluas.Bahwa konsultasi atau pemerikasaan pada waktu ibu hamil dianjurkan minimal $4 \mathrm{x}$, di waktu triwulan pertama satu kali, triwulan kedua satu kali, dan bahkan pada triwulan ketiga dua kali. Meskipun anjuran telah diberikan oleh petugas kesehatan, secara umum ibu hamil baru 
memeriksakan kehamilannya setelah usia kehamilan diatas 4 bulan. Selama kehamilannya mereka kebanyakan hanya memeriksakan kehamilannya dengan bidan kampung.

Menurut informasi dari kepala puskesmas yang bertugas dipuskesmas Kecamatan Seluas, rata-rata ibu hamil masih belum sepenuhnya memanfaatkan pelayanan kesehatan Puskesmas untuk memeriksakan kehamilannya.Kebanyakan mereka lebih senang pergi ke dukun beranak (bidan kampung) yang mereka percayai untuk pemeriksaan kehamilan.

Berdasarkan hasil wawancara bahwa minimnya mereka memeriksakan diri selama kehamilan kebidan dan puskesmas, lebih disebabkan karena mereka kecewa dan beranggapan akan membuang banyak waktu bila memerikasakan ke puskesmas terdekat. Hasil temuan penelitian terungkap:

"Saya pernah memeriksakan kehamilan pada kehamilan memasuki bulan ke 3, pasien yang akan memeriksakan kehamilan waktu itu tidak terlalu banyak.Terlihat mereka menunggu dokternya terlalu lama, setelah saya tanya-tanya rupanya dokternya belum datang. Kondisi tubuh saya yang sedang dalam keadaan ngidam dan rasa kecapean, karena harus menunggu dokternya belum datang. Sejak itu saya malas untuk periksa lagi, sebaiknya ke bidan Kampung/dukun beranak"yang ada di kampong".

Hasil temuan terungkap dari seorang informan yang tidak pernah memeriksakan kehamilannya, karena ia beranggapan bahwa kehamilan adalah peristiwa yang alamiah. Sebab hampir setiap ibu hamil dapat mengalaminya.Sehingga jika ada keluhan selama kehamilan terutama pada tri semester pertama seperti, mual dan pusing merupakan gejala yang biasa.

Mereka tidak menganggap untuk perlu memeriksakannya, terkecuali jika keluhan tersebut sangat mengganggu pekerjaan sehari-hari. Perilaku ibu hamil yang ada keluhan lain dari biasanya dan terasa tidak kunjung sumbuh, mereka terbiasa memeriksakan kesehatan kehamilannya kedukun beranak (bidan kampung) daripada pergi kerumah sakit atau puskesmas.

Selanjutnya dapat ditelusuri bahwa peranan dukun kampung (bidan kampung) dalam pemeriksaan kesehatan perilaku sosial ibu hamil adanya kepercayaan mitos masyarakat terhadap dukun kampung (bidan kampung).Mereka menilai dukun kampong sebagai orang yang dianggap lebih tahu dan dapat memberikan perawatan, pengobatan tradisional, dan pengarahan kepada mereka selama kehamilan.

Menurut mereka biasanya dengan hanya melakukan pemijatan atau mengurut bidan kampung dapat mengetahui bila wanita tersebut sedang dalam kondisi hamil.Begitu juga keadaan bayi yang dalam kandungan, dalam posisi melintang bidan kampung dapat juga mengetahuinya.

Mitos juga berkembang pada sebagian ibu ibu hamil, yakni bila tertidur pada malam, posisi badan sebelah kanan anak yang akan lahir laki-laki dan sebaliknya jika tidur miring sebelah kiri anaknya perempuan. Selanjutnya apabila kendala untuk membetulkan posisi janin yang mengalami pergeseran akibat mengalami kecelakaan terpeleset, atau bekerja terlalu lelah, maka mereka menggunakan jasa bidan kampung dengan cara ibu hamil akan di urut oleh bidan kampung selama 3 hari.

Pemijatannya dilakukan pada pagi hari untuk mengembalikan posisi janin dalam kandungan yang sehat dan sempurna. Apabila tidak berhasil maka ibu hamil merasakan kandungannya terasa sakit dan kecapekan mereka akan pergi kepuskesmas atau kerumah sakit Kabupaten Bengkayang.

Menurut Entjang (2000:17) kehadiran fasilitas kesehatan dan petugas pada suatu wilayah, belum merupakan jaminan yang memberi dampak positif pada kelangsungan hidup anak.Rendahnya penggunaan fasilitas pelayanan kesehatan karena disebabkan oleh berbagai faktor termasuk jarak secara fisik dan secara sosial budaya masyarakat.

Penjelasan kepala puskesmas Kecamatan Seluas Kawasan Perbatasan, menjelaskan bila hasil pemeriksaan yang baik bila dilakukan sedini mungkin dan dilakukan secara rutin kedokter puskesmas.Perilaku sosial ibu hamil yang rutin melakukan pemeriksaan kehamilan, merupakan langkah awal yang baik untuk menjaga kelangsungan hidup untuk ibu hamil maupun bayinya.Agar para pasien dapat teratur, tenaga kesehatan sebaiknya dituntut untuk meningkatkan kualitas pelayanan untuk memeriksakan kehamilan mendapat pelayanan yang memuaskan. Karena dengan pemeriksaan yang baik dapat mendeteksi dini kemungkinan kelainan kehamilan, akan menurunkan kesakitan dan kematian ibu maupun bayinya.

Searah ungkapan Purwandari (2006:67), sebagai anggota profesi bidan mempunyai ciri khas yang khusus, sebagai pelayanan profesional yang notabene merupakan bagian integral dari pelayanan kesehatan.

Berdasarkan wawancara dengan bidan desa dan puskesmas terungkap bahwa mereka tidak memungut biaya dari para ibu hamil yang akan melahirkan. Kebijakan ini merupakan insisiatif Bupati Kabupaten Bengkayang, agar ibu-ibu yang melahirkan kepada bidan desa diseluruh wilayah yang ada di Kabupaten Bengkayang.

Pengalaman peneliti sedang melakukan perjalanan didaerah Kecamatan Seluas Kawasan Perbatasan. Ada seorang ibu-ibu yang habis memeriksakan kehamilannya berjalan sendirian.Dia menempuh jarak yang sangat jauh dari tempat tinggalnya. Keringat membasahi dahiya, nampak bajunya basah dengan keringat sehabis perjalanan. Haus dan lelah kelihatan dari wajahnya, penulis menyodorkan sebotol air, tanpa basa-basi sang ibu menengguk minuman sampai habis.Terlihat wajah ibu menjadi ceria, saat itu peneliti mengantar pulang dengan mobil sewaan. Selanjutnya peneliti bertanya kepada ibu tersebut mengapa ibu selama kehamilan, sering berkonsultasi dengan bidan?. Ibu tersebut menjawab 
dengan lugu, puskesmas lebih paham tentang proses kehamilan.

\section{Persalinan yang diberikan oleh bidan kampung}

Langkah selanjutnya yang perlu dilakukan dalam membahas masalah perilaku sosial ibu hamil dan bersalin adalah mengidentifikasikan apa yang ada sebenarnya.Banyaknya masyarakat mempergunakan jasa yang dimiliki oleh masyarakat tradisional sesuai dengan hasil observasi yang dilakukan oleh penulis di dalam mengumpulkan data dan wawancara mendalam penelitian ini.Bidan kampung memiliki peran yang sangat penting untuk menurunkan angka kematian ibu dan anak.

Peran bidan kampung sebagai pendamping bidan desa memegang tanggung jawab terhadap tugas kepada masyarakat, serta memberikan pelayanan yang terbatas.Ini dikarenakan bidan kampung pendidikannya sangat rendah. Mereka melaksanakan persalinan/melahirkan karena berdasar pengalaman yang ada dan mempergunakan obat-obat tradisional untuk memberikan pengetahuan kesehatan dan mengubah perilaku masyarakat terhadap pola hidup sehat.

Searah ungkapan Poppy (1989:3) mengemukakan definisi yang sangat rinci dari ilmu kesehatan masyarakat adalah suatu ilmu dan seni mengenai cara pencegahan penyakit untuk mencapai perpanjangan masa hidup, dan peningkatan kesehatan fisik dan mental yang berhasil guna melalui pengorganisasian potensi yang ada dalam masyarakat untuk menjaga kesehatan masyarakat dan lingkungan.

Searah dari temuan penelitian dapat ditelusuri, bila faktor sosial budaya, adat kebiasaan, terungkap paradigma perilaku sosial ibu hamil dan melahirkan tidak mungkin dipisahkan dari ilmu kedokteran. Pengobatan secara medis upaya pemeliharan kesehatan individu, masyarakat yang memiliki nilainilai budaya, adat istiadat serta kebiasaannya dapat dilaksanakannnya selama tidak terjadi permasalahan dalam proses kehamilan dan melahirkan.

Selanjutnya Adimihardja, (1999:7) mengungkapkan perwujudan bentuk kearifan tradisi yang merupakan pencerminan budaya lokal di berbagai daerah, memang telah banyak yang hilang dari ingatan masyarakat. Dikalangan masyarakat pengetahuan itu sudah tidak lengkap lagi atau telah berakulturasi dengan pengetahuan baru.Masih tampak ciri-ciri khas dan masih berfungsi dengan baik sebagai pedoman hidup masyarakat pendukungnya.

Berdasarkan hasil temuan penelitian paradigma perilaku sosial ibu hamil terungkap adanya faktor sosial yaitu adat istiadat, kebiasaan yang dilakukan oleh ibu hamil dengan cara melakukan ritual-ritual seperti memperingati hari tujuh bulan dalam masa kehamilan.

Menurut pengakuan seseorang ibu tahapantahapan yang harus dilakukan oleh ibu hamil jika mempergunakan jasa dukun beranak (dukun kampung) harus menggunakan adat istiadat suku dayak, dengan memeberikan seekor anak ayam untuk di potong dengan tujuan memberi hantu atau setan makan supaya persalinan lancer. Setelah itu kayu api sebagai bahan bakar untuk memasak. (dalam bahasa dayaknya waktu dukun beranak (pengarabanan) datang, ia dibarek anak manok untuk ia cancangk marek makan atau ame sampe ngac). Setelah 2 atau 3 minggu (tergantung Nakng baranak) muat adat batalah, manok 2 ekok, nakng udah di munuh dan direbud bolat, tumpik, tungkat powek ka dalam bamboo bontongk, timako jawa, daun rokok nipah, topongk, langir dan minyak makan, sabon, minyak kemiri, kain pacak, sisir, mata bantam, palantar.

Artinya setelah dua atau tiga minggu tergantung yang melahirkan membuat adat memberi nama, ayam dua ekor yang sudah disembelih. Kemudian di potong dan direbus bulat, cucur, ketan yang dimasak kedalam bambu kecil, sepotong, tembakau jawa, daun rokok dari daun nipah.Peralatan nyirih, langir, minyak kelapa, sabun, minyak kemiri, kaian batik, sisir sejumlah uang yang diberikan kepada dukun beranak (bidan kampung), serta beras pulut dan beras biasa merupakan jasa mereka dalam pelaksanaan persalinan.

\section{Jenis Persalinan}

Memasuki masa persalinan merupakan periode yang kritis untuk para ibu hamil, karena segala kemungkinan.Hal ini ditandai oleh adanya gejalagejala dari anak yang lahir dan sikap keluarga dalam menghadapi kegawatan.

Hasil temuan jenis persalinan yang digunakan perilaku sosial ibu hamil untuk menolong diwaktu melahirkan.Menunjukan bahwa terdapat perbedaan informasi dalam memilih pertolongan persalinan. Informasi yang lebih cenderung memilih dukun beranak bidan kampung sebagai penolong persalinan lebih besar dibandingkan dengan bidan praktek dan ke puskesmas.

Kecendrungan ibu hamil menggunakan jasa pertolongan persalinan dibidan kampung dengan alasan keterjangkauan dari segi biaya.Sedangkan menurut hasil temuan dengan beberapa orang mereka lebih memilih puskesmas sebagai tempat pertolongan persalinan, karena jika terjadi sesuatu hal yang tidak di inginkan dapat ditangani segera mungkin.

Terungkap masih sering lambatnya pertolongan persalinan kepada ibu hamil dikarenakan petugas kesehatan puskesmas harus menunggu dokter kandungan yang kadang-kadang jarang di tempat. Hasil temuan juga dapat ditelusuri dari ungkapan informasi, karena tempat tinggal yang agak jauh. Ibu hamil biasanya menggunakan jasa pertolongan persalinan puskesmas bila mereka mendapat kesulitan dalam persalinan atau sudah mengetahui bahwa kehamilannya beresiko tinggi.

Daerah ini seringkali terjadi kematian ibu atau bayi yang baru dilahirkan. Akibat perilaku sosial ibu hamil kurang berkonsultasi atau pemeriksaan secara rutin dengan bidan atau petugas puskesmas di daerah Kawasan Perbatasan Kecamatan Seluas.

Hasil temuan ini dapat ditelusuri kecendrungan yang mendorong perilaku sosial para ibu hamil di waktu persalinan. Dengan cara memilih jasa 
pertolongan bidan kampung. Berdasarkan informasi dan temuan penelitian yang diperoleh pada dasarnya di sebabkan beberapa alasan antara lain, dikenal dekat, biaya murah, juga mudah diminta untuk datang ke rumah.

Dukun beranak juga mengerti dan dapat membantu dalam melakukan pekerjaan rumah tangga, dan dapat membantu upacara adat yang berkaitan dengan kelahiran anak dan merawat ibu bayi sampai umurnya sampai 40 hari. Walaupun sudah banyak bidan kampung yang dilatih, namun praktek-praktek tradisional tertentu masih dilakukan.

Ungkapan kepala puskesmas menyatakan bila kondisi kesehatan ibu hamil dengan kemampuan persalinan sangat menentukan hasil persalinan yakni faktor medis, penyebab kematian ibu-ibu yang hamil, dan yang melahirkan di daerah ini seperti pendarahan, infeksi dan ekslamsia (keracunan kehamilan).

Kondisi-kondisi tersebut bila tidak ditangani secara tepat dan profesional dapat berakibat fatal bagi ibu dalam proses persalinan. Namun, kefatalan sering terjadi tidak hanya karena penanganan yang kurang baik, juga karena adanya keterlambatan pengambilan keputusan dalam keluarga. Pada umumnya di daerah kawasan perbatasan, di sinyalir keputusan terhadap perawatan medis apa yang akan dipilih harus dengan persetujuan kerabat yang lebih tua, atau keputusan berada di tangan suami yang seringkali menjadi panik melihat keadaan kritis yang terjadi kondisi istrinya yang akan melahirkan.

Hasil temuan penelitian diperoleh informasi, walaupun perlengkapan medis termasuk perlengkapan persalinan yang tersedia puskesmas cukup memadai. Namun tenaga tenaga yang berkompeten dibidangnya belum sesuai dengan kebutuhan.Artinya, bahwa tenaga yang ada masih sangat terbatas, untuk melayani para ibu hamil.Terutama untuk melayani wanita yang mengalami gangguan pada masa kehamilan dan melahirkan di kawasan perbatasan Kecamatan Seluas, Kabupaten Bengkayang.

\section{SIMPULAN}

Kemandirian dalam menetapkan dan memenuhi kebutuhannya atas sarana dan prasarana pelayanan kesehatan terutama untuk kesehatan ibu hamil dan melahirkan, melalui bidan desa dan puskesmas tidak seluruhnya direspon oleh masyakarat khususnya oleh ibu hamil. Mereka lebih condong untuk berkonsultasi atau memeriksakan kehamilan mereka kepada bidan kampung ketimbang tenaga puskesmas.Pelaksanaan pelayanan kesehatan ibu hamil dan melahirkan lokasi puskesmas yang terletak di Kecamatan Seluas Kabupaten Bengkayang, juga masih jauh dari sarana dan prasarana yang memadai terutama jalan yang dapat dilalui kendaraan roda empat.

Keengganan masyarakat untuk bersalin di puskesmas, disebabkan oleh beberapa hal yakni; adanya rasa enggan dan malu jika bukan dirumah sendiri.Kemudian, kurang tersedianya fasilitas ruang bersalin dan ruang perawatan.Lebih lanjut pelayanan bidan, dokter di puskesmas sering tidak beradanya di tempat saat warga masyarakat membutuhkan untuk berkonsultasi maupun melahirkan

Perilaku sosial ibu hamil dan melahirkan dilaksanakan oleh bidan kampung atau dukun beranak merupakan suatu bentuk kepercayaan, mitos bahkan budaya adat istiadat yang masih bersahaja. Sebagai penduduk lokal kawasan perbatasan kecamatan Seluas, ada sebagian masyarakat yang menggunakan dan menerima tipe pelayanan perawatan kesehatan kehamilan dan persalinan lebih modern, selama hal tersebut masih terjangkau dari sisi ekonomi dan gratis.

\section{DAFTAR PUSTAKA}

Adimihardja K.1999. Kebudayaan dan Lingkungan. Ilham Jaya: Bandung.

Entjang, Indan. 2000. Ilmu Kesehatan Masyarakat. PT Raja Grafindo: Jakarta.

Garna, Judistira K. 1993. Tradisi,Transformasi, Modernisasi dan Tantangan Masa Depan di Nusantara, Program Pascasarjana, Unpad: Bandung.

Homans, G.C. 1961. Social Behaviur: Its ElementryForm, New York, Harcourt.

Nasution, S. 1996. Metode Penelitian Naturalistik Kualitatif. Tarsito; Bandung.

Poppy, Indan. 1989. Ilmu Kesehatan Masyarakat. PT Raja Grafindo: Jakarta.

Puskesmas Kecamatan Seluas 2013. Data Jumlah Pasien. Kabupaten Bengkayang. Kalimantan Barat.

Purwandari .A. 2006. Konsep Kebidanan, Sejarah dan Profesionalisme. Kedokteran EGC: Jakarta.

Saefullah, D.A. 2008. Pendekatan Kuantitatif dan Kualitatif Dalam Penelitian Lapangan: Khususnya dalam studi kependudukan. Fakultas Ilmu Sosial dan Ilmu Politik Unpad: Bandung:.

Skinner, Q. 1985. (ed.) The Return of Grand Theory in The Human Sciences. Cambridge University Press: Cambridge. 